\title{
Student Perceptions of Student Debt
}

\author{
Stephanie Lally ${ }^{1}$ and Jennifer Gatz ${ }^{1}$ \\ ${ }^{1}$ Patchogue-Medford High School, Medford, NY, USA
}

\section{ABSTRACT}

What would you do if you had 1.16 trillion dollars? Spend it on a vacation? A new car? Something you've been saving up for? According to Perkins et al. (2016), 1.16 trillion dollars is the total amount of outstanding educational debt, otherwise known as student debt. Student debt is created when students borrow money to pay for a room, tuition, books, and other expenses that are necessary for the students to complete a college degree (Craig et al. 2014). Student debt causes many issues for borrowers, such as difficulty transitioning into the real world, limited choice of universities, and having to make sure that investing in college is going to create a larger financial return (Craig et al. 2014; Glater, 2018; Houle, 2015). Limited choice, transitioning after college, and the large investment may negatively affect students' financial stability along with their mental health. Many theories exist as to why these factors have such strong impacts on students, but one main theory is that the media highlights rare situations that have occurred because of student debt rather than common ones. An example of this is how more often than not, articles focus on how a degree does not always guarantee success and puts borrowers into large amounts of debt (Leonhardt, 2014). With this picture of student debt being painted by the media, there is a problem with the amount of knowledge that students have about student debt. Despite more information surfacing, students still may not understand the financial burdens and consequences regarding further payment that these loans bring about. This problem has negatively impacted students because they struggle to repay these loans and handle the debt that they accumulate. A possible cause of this problem is the lack of information available to students. Perhaps a study that investigates student perceptions of student loan debt by a survey may determine factors that could remedy this situation. This leads to my research question, to what extent are high school students concerned about student debt?

\section{Literature Review}

In the literature review to follow, various reports on student debt and specific perceptions of postgraduate debt will be discussed. Examining student debt and its perceptions among high school students are important for understanding how much of an issue academic debt is. The three themes that will be discussed in further detail in the upcoming paragraphs are student debt, the effects of student debt on borrowers' mental health, and perceptions of student debt. It is important to analyze student debt, its effects on students' mental health, and student's perceptions of debt to have a deeper understanding of the effect of college choice and opportunity for secondary school students.

\section{Student debt}

"American families are carrying about $\$ 1.6$ trillion in student loan debt, a massive burden that amounts to nearly 8 percent of national income" (Ingraham, 2019). One reason for the increase in student debt is higher education becoming more accessible. With this new accessibility, many people turned to borrow as their source of funding. In fact, from 2005 to 2012, the number of people who borrowed to pay for higher education increased by $66 \%$ (Craig, 2014). Baum (2017) reached a similar conclusion and found that between 2007 and 2010 total postsecondary enrollment increased by $15 \%$. Baum also highlighted that the percentage of people that had bachelor's degrees and owed $\$ 40,000$ or more rose from 2 to 18 percent between 2003-2004 and 2011-2012. Similar to both Baum's and Craig's findings, 
Schmeiser et al., (2018) found that from 2004-2014 the total number of students with debt increased by 89\%, and their amount of debt increased by $77 \%$ to $\$ 26,000$. With the number of student borrowers increasing, potential students begin to wonder if college is worth the money. In 2018, Glader conducted a study to see how much of a return was necessary for the college to be worth the investment. He found that many students felt that school was worth the investment because there is a greater chance that they would get a high paying job. He also found that for the investment to pay off, borrowers feel a strong pressure to get a high paying job right out of the gate. Relating to the idea of getting a high paying job, Gervais and Ziebarth (2019) commented that many individuals should feel inclined to go out and attempt to work in riskier fields, such as the medical field, where there is a large investment involved but the return is much greater. Some of these jobs don't allow for students to repay their loans due to the salary and having to pay for items that are necessary to live.

When students fail to repay these loans, they are faced with several consequences. One of these consequences is financial instability. Roksa and Arum (2012) found that a significant number of students had to move back in with their families just years after graduating because they could not take on the financial burden of buying a house. However more recently, both Berger and Houle (2015) and Letkiewicz and Heckman (2018) conducted studies to observe any correlation between student debt loans and homeownership. Both studies found no correlation between the two factors, although they did note that the results should not be taken too seriously as different factors could have affected the outcomes such as the most recent changes in the economy. Letkiewicz and Heckman (2018) even went as far to claim that other factors such as the financial lives of graduates, relationship impacts, lifestyle decisions, psychological well-being, and the economy all play a role in students' decisions to purchase a house. Another potential consequence that borrowers face is defaulting on loans. From 2004 to 2014, the number of loans that were defaulted on rose from $2.4 \%$ to $3.2 \%$, and the number of students actively paying loans in 2015 was only $37 \%$. This creates an issue because when borrowers default on loans, they are faced with many consequences that can hurt them not only in the present time but in the future. One of those consequences could be an effect on the students' mental health.

\section{Effects of student debt on mental health}

Student debt not only hurts students financially but damages their mental health as well. In a survey conducted by Roberts et al., (1999), 360 British university students were questioned on several aspects of their health including physical functioning, social functioning, and other general health perceptions. The results from the survey noted that students with loans had poorer functioning psychological and psychosocial dimensions of health than those of students of the same age who were without debt. The researchers attribute this to the fact that many students worked an average of 17.62 hours while in school, which brought on added stress. Similar findings were discovered by Nissen, Hayward, and McManus (2019) when they identified that those with student debt had worse mental health and poorer psychological functioning. They believe that the student's poor mental health came from an "all on me" attitude where students put all their financial responsibilities onto themselves, adding stress into their lives. The researchers also discovered that student loans attributed to delays in milestones such as buying a house, getting married, or starting a family because those involved were not mentally or financially ready.

The mental issues brought about by student loans not only hurt students but affect their ability to have their loans discharged. When students can no longer be financially stable, many file for bankruptcy. The court determines whether or not to discharge loans based on outdated tests that allow for the removal of loans. According to Hancock (2009), many courts are skeptical when it comes to mental health issues and the forgiveness of loans because they believe that these troubles could go away after the debt is forgiven. A great number of courts will not forgive the educational debt if the student has depression because they feel that this is a "curable" disease, and many only forgive the debt if the student has been hospitalized for attempted suicide. Debtors who have bipolar disorder are more likely to have their debt repaid than those who have depression. Some disorders that courts are also skeptical of include anxiety and other panic disorders mainly because the symptoms of these disorders may not persist throughout the rest 
of the student's repayment period (Hancock, 2009). If we could understand and change students' perceptions about their loans, then we could change the number of mental health issues caused by these borrowings.

\section{Student perceptions}

To understand the consequences of student debt, one must first understand how students perceive the economy. In 2018, Hill et al. surveyed a sample of high school students ranging from 9th-11th grade to observe their ideas about the economy. This study found that high school students think about the job market and economy in ways that impact their engagement in school, meaning that negative views of the job market come from students that disengage in hard work and more positive views come from those that are more engaged in their work. Similarly, it found that parents and school-based relationships are critical in helping students plan and understand the job market.

After studying how students view the economy, one can then look into how they view student loans and how those borrowings affect them. Hagemieier et al. (2019) discovered in their study of student pharmacist's finance perceptions that regardless of the student's actual levels of debt, the students were more likely to enter directly into the workforce after graduation as opposed to continuing with post-grad training. Although the students' perceived debt did influence them to go directly into the workforce, it did not have a strong influence on whether or not they would pursue post-graduate training. Similarly, Perkins et al. (2016) also conducted a study to investigate student's perceptions of debt. In this study, 45 students from a private liberal arts university attended a discussion about student debt. From this discussion with students, Perkins et al. (2019) concluded that discussing student debt in the classroom made the students view education as more of an investment as well as increased the students' understanding of the financial burden that student loans can cause. They also found that after listening to the discussion, many students decided to take steps to lessen the amounts of their loans, and one even changed her major due to the high levels and little return that she would have. Many students described this discussion as a "wake-up call" and decided that after hearing about how harmful student loans they were going to do something to shrink the number of loans they left school with. Although this study did not follow up with the students to see if they lowered their debt levels, it is important in showing how much today's students truly know and don't know about student loans.

Overall, student debt is a large issue that is financially and mentally hurting students. These issues are mainly caused by students' perceptions of debt and misunderstandings when it comes to the cost of attending university. One gap in my research is going to be the student perceptions because there is limited knowledge on the perceptions of high school students.

\section{Methods}

During the winter of 2020, 11th, and 12th-grade students at two large, suburban high schools in the Northeast participated in a survey assessing their ideas around student debt. The 16- item survey instrument was administered to participants in high school because should they choose to go onto college, most will have to repay some sort of loan. This instrument was used to reach many students in the limited amount of time that was given.

Table 1. Participant characteristics $(n=148)$

\begin{tabular}{|c|c|c|c|c|c|c|}
\hline & Age & Grade & Gender* & $\begin{array}{c}\text { Mothers socio- } \\
\text { economic sta- } \\
\text { tus** }\end{array}$ & $\begin{array}{c}\text { Fathers socio- } \\
\text { economic sta- } \\
\text { tus**** }\end{array}$ & Ethnicity**** \\
\hline Mean & 16.30 & 11.16 & 1.43 & 3.57 & 3.38 & 4.59 \\
\hline Standard deviation & 0.51 & 0.37 & 0.54 & 1.44 & 1.53 & 1.23 \\
\hline
\end{tabular}


Codes:

*Rank order 0: Prefer not to say Rank order 1: Male Rank order 2: Female

**Rank order 0: Not applicable Rank order 1: Some high school Rank order 2: Completed high school Rank order 3: Some college Rank order 4: Completed college degree Rank order 5: Graduate degree

***Rank order 0: Not applicable Rank order 1: Some high school Rank order 2: Completed high school Rank order 3: Some college Rank order 4: Completed college degree Rank order 5: Graduate degree

****Rank order 1: American Indian or Alaska Native Rank order 2: Asian Rank order 3: African American Rank order 4: Hispanic Rank order 5: White Rank order 6: Native Hawaiian or other Pacific Rank order 7: Other

Participant characteristics are shown above in Table 1. The objective of this study was to find out how concerned students are about student debt and this was achieved by modeling the high school version of the Ascent Funding's 2019 National Study of Perceptions \& Realities of Paying for College. The purpose of using this survey was to test a series of hypotheses surrounding students' ideas about student debt and their plans for handling it in the future. Questions were taken out of the survey and modified to fit this study, which was then administered to students by their teachers and was also sent out through social media platforms such as Snapchat. Before taking the survey, students were informed that their responses were voluntary and kept confidential. The survey asked a series of questions surrounding students' ideas about student debt such as "Do you plan on attending college?" "What is the most important factor that you consider when applying for college?" and "How important is the cost of school when making a final decision?" All of these questions were asked to try and supply a response to the hypothesis that if students plan on going to college then they will be extremely concerned about the cost. The survey then asked students questions about their research and feelings about student debt.

This was done by asking "Who did the majority of the research when it came to college expenses and financial aid?" and "Overall, how knowledgeable do you feel you are about the options to pay for college?" These questions were asked to provide feedback on the hypothesis that students are not very confident in their abilities to repay college expenses. The survey then questioned students on how they planned to repay college debts, how confident they felt about their abilities to do that, and who they received the most information from. This was meant to supply a response to the hypothesis that students will have done a majority of the research on their own and that they are not very confident in their abilities to repay the debt. Students were finally asked whether they viewed a college education as a transactional or transformational investment. This was to try and see if there was any correlation between how the students viewed school and how concerned they were about the debt they would acquire from it. Although response selection varied by a question, many were answered by choosing how confident or knowledgeable the student felt about what was presented in the question. An example of an exception for this could be "What is the most important factor that you consider when applying for college?" because students had to choose from a list of factors, some including cost, location, and sports teams.

\section{Results}

A total of 148 usable responses were produced between both high schools. Overall, 99.32\% of the students that participated planned on going to college after high school and $.68 \%$ did not. The results gathered from the survey are shown in the table 2. 
Table 2: Student responses to perceptions of student debt $(n=148)$

\begin{tabular}{|c|c|c|}
\hline Question & M & SD \\
\hline Most important factor & 3.05 & 2.00 \\
\hline Importance of cost & 2.76 & 1.07 \\
\hline Who completed the research & 1.69 & 0.90 \\
\hline $\begin{array}{c}\text { Accurate understanding of a college } \\
\text { education }\end{array}$ & 2.20 & 1.09 \\
\hline $\begin{array}{c}\text { Knowledge when it comes to options } \\
\text { to pay for college }\end{array}$ & 2.14 & 0.98 \\
\hline $\begin{array}{c}\text { onfidence in the ability to repay the } \\
\text { money after graduation }\end{array}$ & 2.24 & 1.11 \\
\hline $\begin{array}{c}\text { What source have you received the } \\
\text { most information from }\end{array}$ & 2.99 & 1.43 \\
\hline $\begin{array}{c}\text { Ss college a transactional or transfor- } \\
\text { mational investment? }\end{array}$ & 1.31 & 0.46 \\
\hline
\end{tabular}

Student participants were also asked how they planned on paying for college and were asked to choose as many options as they felt necessary. Student responses are shown in the table 3.

Table 3: Student responses to paying for college $(n=148)$

\begin{tabular}{|c|c|}
\hline Options: & Number of students: \\
\hline Student funded by working/jobs & 62 \\
\hline A parent providing support/funding & 112 \\
\hline Merit-based aid/scholarship & 86 \\
\hline Federal loans & 42 \\
\hline Private loans & 18 \\
\hline Need-based aid from the college & 35 \\
\hline Other & 3 \\
\hline
\end{tabular}

To see if any correlations were present with the data, a spearman's rank-order correlation analysis was run and there were significant correlations between several variables. All of the correlations were positively correlated and spearman rho values are shown in table 4 . 
Table 4: Correlations with spearman values $(n=148)$

\begin{tabular}{|c|c|c|c|c|c|}
\hline Variables & $\mathbf{1 .}$ & $\mathbf{2 .}$ & $\mathbf{3 .}$ & $\mathbf{4 .}$ & $\mathbf{5 .}$ \\
\hline $\begin{array}{c}\text { 1. Mothers socio- } \\
\text { economic status }\end{array}$ & - & & & & \\
\hline $\begin{array}{c}\text { 2. Fathers socio- } \\
\text { economic status }\end{array}$ & $<.001^{* * *}$ & - & & & \\
\hline 3. Research & $.01^{*}$ & $.01^{* *}$ & - & & \\
\hline $\begin{array}{c}\text { 4. Accurate un- } \\
\text { derstanding }\end{array}$ & $.001^{* *}$ & $.003^{* *}$ & .84 & - & \\
\hline $\begin{array}{c}\text { 5. Most important } \\
\text { factor }\end{array}$ & $.002^{* *}$ & $.04^{*}$ & .20 & .16 & \\
\hline
\end{tabular}

$* \mathrm{p}<.05 * * \mathrm{p}<.01 * * * \mathrm{p}<.001$

One relationship that can be shown between variables is that as the socioeconomic status of the mother and the father increase, so does the students' understanding of the total cost of a college education. As the socioeconomic status of the mother and father increase, so does the person who completed a majority of the research about college, meaning a non-parent or outside advisor was used. Another finding is that as the socioeconomic status of the mother and father increased, so did the most important factor for the students, meaning they valued sports and location over the other factors. It was also found that as the student's grade level increases, so does their understanding of the total cost of a college education. One implication that presented itself was that as the student's grade level increased, so did their interests in college and careers. This meant that their research and education levels surrounding college were more present and they had a better understanding of how this would affect them. This is supported by the study conducted by Hill et al. which found that students in the higher grades had a better understanding of the economy and how it would affect them.

\section{Discussion and conclusions}

The focus of this paper was to respond to the question, to what extent are high school students concerned about student debt? The hypothesis proposed was that the students would be highly concerned about having debt after college. Although there was no correlation found between students' grades and their concern with student debt, the study did show that students were only moderately confident in their abilities to repay their loans before graduation. This is a significant finding because it correlates to the findings of Perkins et al (2019), who found that $60 \%$ of the students that took part in their study were expected to have debt after graduation. Another similarity arose when students were asked how they planned to repay the money that they borrowed for college. Students were given options such as taking out loans, having help from parents, scholarships from the schools, and other similar choices. From this question, 112 students out of the 148 had selected that they planned on relying on their parents to aid them in repaying their borrowed money. This finding was similar to that of Gervais and Ziebarth (2019) because in their study they claimed that $63 \%$ of the graduates received financial assistance from their parents and that a majority depend on their family for financial assistance. This is significant because the findings corroborate each other in that both investigations found that parents played a somewhat large role in the student's post-graduate financial situation.

A similar finding that was also presented from that question was that several students planned on borrowing money in some form of a loan, whether it be private or federal. This is backed up by the findings of Craig et al. (2014) 
because, in their study, they claimed that as access to higher education increases, so does the number of American students that borrow loans. This is significant because loans can lead the students to delay major milestones after graduation, as stated by Nissen, Hayward, and McManus (2019), as well as can harm their mental state, as claimed by Hancock, (2009). The gap in my research was the perception of student debt in high school students as compared to previous students conducted on college students by Perkins et al. One unexpected finding that came out of this study was who participants had received the most information from about the total cost of a college education. $42 \%$ of students said that they received the most information from personal research but only $5 \%$ said that they had been provided with the information from a guidance counselor. This finding was unexpected because it was hypothesized that guidance counselors would be providing the most information to the students since that is one of the main focuses of their job.

This study was significant because it helped to assess how much students truly know about student debt. That is important because student debt has many diminishing consequences such as financial instability, delay of plans, and mental health issues. Like any good study, limitations are a factor to be considered. Some limitations that presented themselves were the fact that my participants were mainly white students, there was a relatively small sample size and a majority of the students that took the survey were AP students. Although this is a limitation, it does aid in the research because it means that more students will plan on going to college. Future researchers should consider using a larger sample size or conducting the research over a larger area.

\section{Acknowledgments}

I would like to thank all of those involved that made it possible to conduct this study and write this report. This includes my advisor, Dr. Gatz, the teachers that gave this survey to their students, Mr. Alfano and Mrs. Vollaro, and all the students that took part in this study. This would not have been possible without the help of all of you.

\section{References}

Ascent funding's 2019 national study of perceptions \& realities of paying for college. (2019, March). In Ascent. Retrieved from https://ascentstudentloans.com/blog/2019/04/29/ascent-fundings-2019-national-study/

Baum, S. (2017). STUDENT DEBT: Good, Bad, and Misunderstood. Change, 49(3), 60-70. https://doi.org/10.1080/00091383.2017.1321442

Craig, J. D., \& Raisanen, S. R. (2014). Institutional determinants of American undergraduate student debt. Journal of Higher Education Policy \& Management, 36(6), 661-673. https://doi.org/10.1080/1360080X.2014.957892

Gervais, M., \& Ziebarth, N. L. (2019). Life After Debt: Postgraduation Consequences of Federal Student Loans. Economic Inquiry, 57(3), 1342-1366. https://doi.org/10.1111/ecin.12763

Glater, J. D. (2018). The Narrative and Rhetoric of Student Debt.Utah Law Review, 2018(4), 885-895. Retrieved from http://search.ebscohost.com/login.aspx?direct=true $\& \mathrm{db}=\mathrm{a} 9 \mathrm{~h} \& \mathrm{AN}=130855082 \&$ site=ehost-live

Hagemeier, N. E., Gentry, C. K., Byrd, D. C., Cross, L. B., Rose, D., Ansari, N., ... Branham, T. (2019). Student Pharmacists' Personal Finance Perceptions, Projected Indebtedness Upon Graduation, and Career Decision-making. American Journal of Pharmaceutical Education, 83(4), 580-586. Retrieved from http://search.ebscohost.com/login.aspx ?direct $=$ true $\& d b=a 9 h \& A N=137144664 \&$ site $=$ ehost-live 
Hancock, K. E. (2009). A Certainty of Hopelessness: Debt, Depression, and the Discharge of Student Loans under the Bankruptcy Code. Law \& Psychology Review, 33, 151-166. Retrieved from http://search.ebscohost.com/login.aspx?direct=true $\& d b=a 9 h \& A N=50318100 \&$ site $=$ ehost-live

Henager, R., \& Wilmarth, M. J. (2018). The Relationship Between Student Loan Debt and Financial Wellness. Family \& Consumer Sciences Research Journal, 46(4), 381-395. https://doi.org/10.1111/fcsr.12263

Hill, N. E., Liang, B., Bravo, D. Y., Price, M., Polk, W., Perella, J., \& Savitz-Romer, M. (2018). Adolescents' Perceptions of the Economy: Its Association with Academic Engagement and the Role of School-Based and Parental Relationships. Journal of Youth \& Adolescence, 47(5), 895-915. https://doi.org/10.1007/s10964-017-0802-5

Houle, J. N., \& Berger, L. (2015). Is Student Loan Debt Discouraging Homeownership among Young Aduits? Social Service Review, 89(4), 589-621. https://doi.org/10.1086/684587

Ingraham, C. (n.d.). 7 ways $\$ 1.6$ trillion in student loan debt affects the U.S. economy. The Washington Post. Retrieved from https://www.washingtonpost.com/business/2019/06/25/heres-what-trillion-student-loan-debt-is-doingus-economy/

Leonhardt, D. (n.d.). Is College Worth It? Clearly, New Data Say. ny times. Retrieved from ny times database.

Letkiewicz, J. C., \& Heckman, S. J. (2018). Homeownership among Young Americans: A Look at Student Loan Debt and Behavioral Factors. Journal of Consumer Affairs, 52(1), 88-114. https://doi.org/10.1111/joca.12143

Nissen, S., Hayward, B., \& McManus, R. (2019). Student debt and wellbeing: a research agenda. Kotuitui: New Zealand Journal of Social Sciences, 14(2), 245-256. https://doi.org/10.1080/1177083X.2019.1614635

Perkins, D., Johnston, T., \& Lytle, R. (2016). Addressing student debt in the classroom. Journal of Education for Business, 91(3), 117-124. https://doi.org/10.1080/08832323.2016.1140112

Roberts, R., \& Golding, J. (1999). The Effects of Economic Circumstances on British Students' Mental and Physical Health. Journal of American College Health, 48(3), 103. https://doi.org/10.1080/07448489909595681

Roksa, J., \& Arum, R. (2012). Life after College: The Challenging Transitions of the Academically Adrift Cohort. Change, 44(4), 8-14. https://doi.org/10.1080/00091383.2012.691857

Ross, S., Cleland, J., \& Macleod, M. J. (2006). Stress, debt and undergraduate medical student performance. Medical Education, 40(6), 584-589. https://doi.org/10.1111/j.1365-2929.2006.02448.x

Stoddard, C., Urban, C., \& Schmeiser, M. D. (2018). College Financing Choices and Academic Performance. Journal of Consumer Affairs, 52(3), 540-561. https://doi.org/10.1111/joca.12175 